Steel," what purports to be a "novel" method of determining carbon by a modification of the Eggertz process; as this "new" method has probably been practiced ever since the Eggertz process was introduced, I think it is time a protest was entered against such self-evident modifications being published as original. I do not know to whom this particular method of dilution is originally due, but it has been used by nearly all steel works chemists in this country for the past 17 or 18 years to my personal knowledge.

A modification of the Eggertz process which I do not know to be so commonly used, as it might well be, refers to the determination of carbon in very soft steel, etc., and when the carbon is below $0.10 \%$, is carried out by weighing a portion of a standard steel, say 0.1 gram, and adding o.I gram of the sample to it; this is dissolved alongside a 0.2 gram portion of the same (or other) standard and the two compared, when a simple calculation will give the result for the steel.

Any one who is associated with the comparison of low carbon steels, $i$. e., steel with carbon under about o. Io per cent., will be acquainted with the difficulty of comparison on account of the greenish tint; the above process is designed to overcome.this difficulty and I can confidently recommend its trial.

While on the subject of carbon determination, I might mention that I have successfully used a similar process in connection with the determination of carbon by direct combustion in oxygen of the more refractory ferro alloys: by placing a known quantity of a standard steel in the combustion boat and sprinkling the weighed portion of the alloy over this, when the heat generated by the combustion of the steel standard has been sufficient to insure complete combustion of the alloy.

I am not claiming originality for these modifications which are in this country looked upon merely as "shop kinks."

IABORATORY OF The BRYMBo STEEL WORKS,

E. EsCOTT WOOD. WREXHAM, WALES.

\section{A COLORIMETRIC METHOD FOR THE DETERMINATION OF CARBON IN IRON AND STEEL-A NOTE.}

Editor of the Journal of Industrial and Engineering Chemistry:

In the May issue of THIs Journal for the current year there appeared an article entitled "A Colorimetric Method for the Determination of Carbon in Iron and Steel." This method is claimed to be similar to the one proposed by Eggertz. This statement was very surprising to me because I had studied Eggertz' method under him in the Royal Mining School at Stcckholm, Sweden, and later, in my own laboratory, I made about five thousand determinations using his method. When reading Mr. Kohout's method, I found same identical with Prof. Eggertz' method. At - present I can only refer to a foot-note in Blair, "Analyses of Iron and Steel" on page 170,5 th edition, and page 175 , concerning the dilution of the standard.

$$
\text { Yours very truly, }
$$

C. G. Hellman.

165 GRAND STREET,

JERSEY CITY, N. J.

\section{VALUATION OF FLUORSPAR-A CORRECTION.}

In my article in this paper, Vol. 4, No. 3, March, I9I2, I quoted incorrectly Mr. F. Julius Fohs' statement published in Bulletin 9 of the Kentucky Geological Survey, iiz., "silicates occurring associated with Kentucky fluorspar." The word "Kentucky" should be omitted: it disturbs the meaning of the following discussion, changing the same to a depreciative criticism of Mr. Fohs' statement, which I did not intend to do. Mr. Fohs states that the silicates mentioned in my article occur occasionally associated with fluorspar, but not with Kentucky fluorspar.

ERNST BIDTEL.

\section{GENERAL BAKELITE COMPANY STARTS INFRINGEMENT SUITS.}

General Bakelite Company has brought suits for infringements of its Bakelite patents against the Condensite Company of America and several users of "Condensite;" among them the Dickinson Manufacturing Co. of Springfield, Mass., The Duranoid Mfg. Co. of Newark, N. J., and Hardman \& Wright of Belleville, N. J.

In relation to this, it is of interest to note that the fundamental Bakelite patents have been allowed in Germany and have been sustained by the German Patent Office, notwithstanding the fact of several public contestations.

\section{THE END OF THE COÖPERATIVE GLASS FACTORIES IN ITALY.}

In the "Fachgenosse", 28 , No. 58 (an organ of the German glass unions), appears an article noting the failure of the coopperative glass factories of Italy in their struggle with the trust (cf. $C$. $A$, 5, 166).

These rival glass factories were started by the labor unions in I903 with the small capital of $\$ 5,750$. They proceeded to compete with the trusts for the control of the market, hoping at least to compel recognition of their union and improve conditions for the men. During the last nine years these factories have been increased to seven in number at the time of the bankruptcy. Business conditions in the Italian glass industry throughout the last year particularly have been very unfavorable. In I9 Io occurred a shortage in the grape crop result in a lessened demand for bottles, and the Turko-Italian war proved to be the last straw in the situation for the coopperative factories. They were scattered over the northern part of Italy, with the exception of one factory in the vicinity of Naples, and with their scanty capital and lack of close coöperation were unable to cope with the hard times and consequent losses.

J. B. Patch.

\section{INTERNATIONAL CONGRESS OF APPLIED CHEMISTRY. ANNOUNCEMENT BY SECTION I, ANALYTICAL CHEMISTRY.}

The President of Section I, Analytical Chemistry of the approaching Congress of Applied Chemistry, desires to call the attention of chemists to an official notification received by him, that two important propositions will be advocated at the Congress.

It will be moved by the Verein deutscher Chemiker: To adopt for practical purposes an atomic weight table only once in five years and on a given date to introduce this generally and recognize it as binding in mutual dealings.

The Sectional Group, "Analytical Chemistry," of the Verein deutscher Chemiker will make the following suggestion:. To request the Sub-committee on Uniform Sampling of the International Committee on Analyses to take up the sampling of ores.

For fuller details, consult Chemiker Zeitung, June 6, page 635 , and Zeitschrift für angewandte Chemie, June 7, page II7I. 